\title{
EFFICACY OF GENITAL CHLAMIDIAE TRACHOMATIS TREATMENT IN WOMEN OF REPRODUCTIVE AGE
}

\author{
Aleksandra Dimitrijevic, Zoran Protrka, Nikola Jovic, Petar Arsenijevic \\ Department of Gynecology and Obstetrics, Faculty of Medical Sciences, University of Kragujevac, Kragujevac, Serbia \\ Clinic of Obstetrics and Gynecology, Clinical Center Kragujevac, Kragujevac, Serbia
}

\author{
EFIKSANOST TERAPIJE GENITALNIH INFEKCIJA HLAMIDIJOM \\ TRAHOMATIS KOD ŽENA U REPRODUKTIVNOM PERIODU \\ Aleksandra Dimitrijević, Zoran Protrka, Nikola Jović, Petar Arsenijević \\ Katedra za ginekologiju i akušerstvo, Fakultet medicinskih nauka Univerziteta u Kragujevcu, Kragujevac, Srbija \\ Klinika za ginekologiju i akušerstvo, Klinički centar Kragujevac, Kragujevac, Srbija
}

\begin{abstract}
Cervicitis is inflammation of the cervix, and the causes of such inflammation may include infection from certain sexually transmitted diseases (STDs), injury to the cervix from a foreign body inserted into the vagina (for example, birth control devices such as a cervical cap or diaphragm), or cervical cancer, whose course can be subacute or chronic. Our research aimed to test the efficacy of the proposed treatment protocol for chlamydia trachomatis distal genital infections in reproductive women. This single-centre, randomized, quasi-experimental prospective study was conducted among 40 women with diagnosed Chlamydia Trachomatis (CT) cervical infections who were diagnosed and treated at the Clinic of Obstetrics and Gynaecology in the Clinical Center Kragujevac in Serbia from December 2014 to January 2015. Patients were divided into two groups according to the treatment method: the tetracycline group $(n=20)$, with doxiciclyn (Dovicin $\left.{ }^{\circ}\right)$ given at a dose of $100 \mathrm{mg}$ twice per day for 10 days and $100 \mathrm{mg}$ per day for the next 10 days, and the macrolides group $(n=20)$, with azithromycin (Hemomycin ${ }^{\circ}$ ) at a dose of $1000 \mathrm{mg}$ per day, divided into four doses or a single dose per day. Treatment with doxycycline proved to be statistically more effective compared to treatment with azithromycin. Our results confirm that the outcome of infections caused by C. trachomatis depends solely on the applied therapy and management, but extensive prospective studies in a female cohort that includes more parameters, such as potential age related, dose-dependent and adherence variability, are necessary to determine and confirm the best choice for treatment of CT cervicitis.
\end{abstract}

Keywords: Chlamydia Trachomatis, cervicitis, Tetracyclines, Macrolides

\section{SAŽETAK}

Cervicitis je bolest od koje oboli oko 50\% svih žena, a najčešci izazivač je Chlamidia trachomatis.Chlamidia trachomatis je i najčešća seksualno prenosiva bolest.

Prospektivna studija sprovedena u klinici za Ginekologiju $i$ akušerstvo obuhvatila je 40 pacijentkinja kod kojih je analizom cervikalnog brisa utvrđeno prisustvo Chlamidiae trachomatis nakon čega su one lečene različitim terapijskim protokolima i pri tome ispitivana efikasnost terapije.Prema terapiskom protokolu pacijentkinje su bile podeljene u dve grupe. Prva grupa u kojoj je bilo 20 pacijentkinja lečena je tetraciklinima, a druga grupa makrolidnim antibioticima.

Analizom dobijenih rezultata utvrdeno je da je u grupi pacijentkinja lečenih tetraciklinima po završenoj terapiji Chlamidia trachomatis bila prisutna u brisu cerviksa kod 15\% pacijentkinja, u $85 \%$ slučajeva nalaz je bio negativan. U grupi pacijentkinja lečenih makrolidima pozitivan nalaz Chlamidiae trachomatis zabeleženje u $85 \%$ slučajeva, a samo $15 \%$ pacijentkinja po završenoj terapiji nije više imalo Chl. Trachomatis u cervikalnom brisu.

Lečenje tetraciklinima pokazalose statistički značajno efikasnije u odnosu na lečenje makrolidnim antibioticima. Prema tome i drugim rezultatima naseg istrazivanja, terapija izbora za lecenje Chlamidiae trachomatis treba da bude doksiciklin.

Ključne reči: Chlamydia trachomatis, cervicitis, inflamacija grlića materice, tetraciklini, makrolidi 


\section{INTRODUCTION}

Cervicitis is inflammation of the cervix, and the causes of such inflammation include infection from certain sexually transmitted diseases (STDs), injury to the cervix from a foreign body inserted into the vagina (for example, birth control devices such as a cervical cap or diaphragm), or cervical cancer $(1,2)$ whose course can be subacute or chronic.

Infectious cervicitis may be caused by Chlamydia trachomatis (CT), Neisseria gonorrhoeae or herpes simplex virus (HSV), but the inciters may be bacteria, viruses and fungi. In smears of the cervixes of women who were diagnosed with cervicitis, the presence of the Gram-negative obligate intracellular bacteria Chlamydia trachomatis found in approximately $20 \%$ of the cases, and it is considered the most common cause of Chlamydia trachomatis cervicitis (3-5).

According to the sexually transmitted diseases treatment guidelines from 2010, two major diagnostic signs characterize cervicitis: 1) a purulent or mucopurulent endocervical exudate visible in the endocervical canal or on an endocervical swab specimen (commonly referred to as mucopurulent cervicitis or cervicitis) and 2) sustained endocervical bleeding that is easily induced by gentle passage of a cotton swab through the cervical os. Either or both signs might be present. Cervicitis is frequently asymptomatic, but some women complain of an abnormal vaginal discharge and intermenstrual vaginal bleeding (e.g., after sexual intercourse). A finding of leucorrhoea ( $>10 \mathrm{WBC}$ per high-power field on microscopic examination of vaginal fluid) has been associated with chlamydial and gonococcal infections of the cervix. In the absence of inflammatory vaginitis, leucorrhoea might be a sensitive indicator of cervical inflammation with a high negative predictive value (6).

The infection is very often asymptomatic; more than 70 $\%$ of women have no symptoms $(7,8)$. The infection, other than sexual contact with an infected partner, can be transmitted vertically if pregnancy occurs, i.e., in childbirth during the passage of the foetus through the birth canal of the infected mother. Newborn infections manifest clinically as oftalmia neonatorum in $50 \%$ of cases or as pneumonia in $20 \%$ of cases $(9,10)$.

The symptoms of cervicitis induced by $\mathrm{C}$. trachomatis are vaginal discharge, pain in sexual intercourse and pain interference with defecation (11-13). The diagnosis of cervicitis induced by Chl. trachomatis typically is made with the following (14-19): isolation of the carrier in the respective cell culture; identification of the chlamydia antigen (DIF, immunosorbent assays, DNK hybridization, PCR and LCR); and serological tests for the detection of a specific antibody (response complements fixation, test indirect fluorescence, and ELISA-test).

When treating cervical infections caused by $\mathrm{C}$. trachomatis, antibiotics are applied that penetrate well into the host cell because it is sensitive to antibiotics only in the reticular body during the process of division within the cytoplasm. Currently, this is considered the most effective method of treatment with antibiotics from the tetracycline and macrolide groups (20-22).

The Centers for Disease Control and Prevention (CDC) suggest that several factors should affect the decision to provide presumptive therapy for cervicitis or to await the results of diagnostic tests. Treatment with antibiotics for C. trachomatis should be provided for those women who are at an increased risk for this common STD (e.g., those aged $\leq 25$ years, those with new or multiple sex partners, and those who engage in unprotected sex). The recommended regimens for presumptive treatment of cervicitis caused by CT is $1 \mathrm{~g}$ of azithromycin orally in a single dose or $100 \mathrm{mg}$ of doxycycline orally twice a day for seven days (6).

Tetracyclines are naphthacene derivatives that inhibit protein synthesis and act bacteriostatic, and the macrolide inhibits protein synthesis and acts bacteriostatic.

Many follow-up studies have been conducted as recommended in different guidelines and according to empirical knowledge, but it is still unclear if doxycycline treatment is more efficacious than azithromycin in the management of cervicitis caused by Chlamydia.

Our research was aimed to test the efficacy of the proposed treatment protocol for Chlamydia trachomatis distal genital infections in women of reproductive age.

\section{PATIENTS AND METHODS}

\section{Study design and setting}

This single-centre, randomized, quasi-experimental prospective study was conducted among 40 women who were diagnosed with Chlamydia Trachomatis (CT) cervical infections and were diagnosed and treated at the Clinic of Obstetrics and Gynaecology in the Clinical Center Kragujevac in Serbia from December 2014 to January 2015.

Women $\geq 20$ years of age who were confirmed to have a CT infection were divided into two groups according to the treatment method: Tetracyclines group and Macrolides group. The first group of patients was treated by tetracycline antibiotics $(n=20)$, i.e., Doxiciclyn $\left(\right.$ Dovicin $\left.^{\circ}\right)$, at a dose of $100 \mathrm{mg}$ twice per day for 10 days and $100 \mathrm{mg}$ per day for the next 10 days. The second group was treated by macrolide antibiotics $(n=20)$, i.e., Azitromycin (Hemomy$\mathrm{cin}^{\circ}$ ), at a dose of $1000 \mathrm{mg}$ per day, divided into four doses or a single dose per day.

\section{Detecting Chlamydia trachomatis (CT) Infections}

In all patients, localized $\mathrm{CT}$ infections were examined by assays for direct pathogen detection, such as culture, antigen tests (direct fluorescent antibody (DFA), and immune chromatographic RDTs), nucleic acid hybridization and amplification tests as previously described (23). The established cell lines for isolating $\mathrm{C}$. trachomatis include Mc Coy, HeLa 229 or Buffalo Green Monkey Kidney cells. Vaginal and endocervical swabs are suitable specimens for culture but must be collected using special devices and 
transport media (24). Specimens were centrifuged onto a confluent cell monolayer and analysed for the development of characteristic intracytoplasmic inclusions after 48-72 h by staining with Giemsa, iodine, or fluorescence labelled antibodies to chlamydial antigens (LPS or MOMP). When using MOMP-specific antibodies for staining cell culture, the detection is highly specific, so this method has long been considered the reference test for CT detection (25).

During follow-up, samples were collected before and after antibiotic therapy from the endocervix and tested for CT.

\section{Participant Selection}

Inclusion criteria were the reproductive period of a woman who was diagnosed with CT cervicitis. Exclusion criteria were a previous allergic reaction to an antibiotic medicine or the same therapy applied with a partner. Additionally, clinical, biochemical, haematological and additional examinations were excluded for cardiovascular, neurological, endocrine and malignant conditions. To minimize bias, members of the test and control groups were fully comparable (matched-subjects). All participants provided written informed contest.

Treatment outcomes were cervicitis or vaginal symptoms and CT tests at follow-up.

All participants were asked to complete a questionnaire that included the following information: age, consumption of alcohol and cigarettes, age of first sexual contact, number of previous births and abortions, length of sexual life and number of sexual partners.

\section{Statistical analyses}

Descriptive statistics, hypothesis tests and logistic regression were included as statistical analyses methods. Measures of central tendency (arithmetic mean) and variability (SD, min, max) were used in descriptive statistics. Hypothesis testing was applied to the numerical insignia of the observation and analysis of the frequency of categorical variables. Before testing numerical variables, the type of distribution was assessed. For a normal distribution of data, a t-test and analysis of variance (ANOVA) were applied; in nonparametric statistics (distribution was not normal), a Mann-Whitney U-test was applied. To analyse the frequency of observed parameters, a Hi square test, Fisher's test and Mc Nemar's test were used, depending on the structure of data. In all hypothesis testing cases, the probability of the zero (null) hypothesis was $p \leq 0.05$. To estimate the importance of the impact of individual risk factors in relation to the dichotomous outcome, a logistic regression model, with univariate and multivariate regression analysis was used.

\section{RESULTS}

\section{Demographic and anamnestic data}

All women were in the range of 20 to 35 years old. In the doxycycline group, patients had fewer years of sexual
Table 1. Anamnestic data of all participants obtained from the questionnaires prior to follow-up. All data are presented as the mean $\pm \mathrm{SD}$, minimum, maximum and/or frequencies in percent (\%).

\begin{tabular}{|c|c|c|c|}
\hline \multicolumn{2}{|c|}{ PARAMETERS } & $\begin{array}{c}\text { Doxycycline } \\
\text { treatment }\end{array}$ & $\begin{array}{l}\text { Azitromycine } \\
\text { treatment }\end{array}$ \\
\hline \multicolumn{2}{|c|}{ Year of sexual relations $\left(X_{ \pm} S D\right)$} & $15.25 \pm 2.51$ & $18.35 \pm 2.06$ \\
\hline \multicolumn{2}{|c|}{ Number of partners (min-max) } & $5(2-8)$ & $5-6(3-7)$ \\
\hline \multirow{4}{*}{$\begin{array}{l}\text { Spontaneous } \\
\text { abortions }\end{array}$} & no & $17(85 \%)$ & 17 (85\%) \\
\hline & two & $3(15 \%)$ & $1(5 \%)$ \\
\hline & three & $0(0 \%)$ & $1(5 \%)$ \\
\hline & four & $0(0 \%)$ & $1(5 \%)$ \\
\hline \multirow{3}{*}{$\begin{array}{l}\text { Induced } \\
\text { abortions }\end{array}$} & no & $19(95 \%)$ & $19(95 \%)$ \\
\hline & two & $0(0 \%)$ & $1(5 \%)$ \\
\hline & there & $1(5 \%)$ & $0(0 \%)$ \\
\hline \multirow{4}{*}{ Deliveres } & no & $16(80 \%)$ & $16(80 \%)$ \\
\hline & one & $1(5 \%)$ & $2(10 \%)$ \\
\hline & two & $2(10 \%)$ & $2(10 \%)$ \\
\hline & theree & $1(5 \%)$ & $0(0 \%)$ \\
\hline \multirow{2}{*}{ Contraception } & Yes & $3(15 \%)$ & $8(40 \%)$ \\
\hline & No & $17(85 \%)$ & $12(60 \%)$ \\
\hline \multirow{2}{*}{$\begin{array}{c}\text { Type of } \\
\text { contraception }\end{array}$} & $\begin{array}{c}\text { condom } \\
\text { contraception } \\
\text { occasionally }\end{array}$ & $3(15 \%)$ & $7(35 \%)$ \\
\hline & $\begin{array}{c}\text { oral } \\
\text { contraceptives }\end{array}$ & $0(0 \%)$ & $1(5 \%)$ \\
\hline
\end{tabular}

relationships and fewer partners during their sexually active history. The frequencies of spontaneous and induced abortions were similar in both groups, as was that of deliveries. The use of contraception was more frequent in the azithromycin group compared to the doxycycline group, in which predominant use of condom contraception occurred occasionally and oral contraception occurred constantly (Table 1).

\section{CT tests before and after doxycycline/azithromycin treatment}

The outcomes of therapy are verified and cervical smears were compared before and after the therapy. Treatment with doxycycline proved to be statistically more effective compared to treatment with azithromycin. Based on the relative risk for a bad outcome, the efficacy of doxycycline therapy was 32 times higher than the effectiveness of treatment with azithromycin.

The cervical smear with Chlamydia trachomatis was significantly different before and after doxycycline treatment (Mc Nemar test; $\mathrm{p}=0.000$ ). Before the therapy, all patients had a positive swab for cervix Chlamydia T. After therapy, a positive swab result was found only in $15 \%$ of the respondents, and $85 \%$ of the cervical swabs for Chlamydia were negative, as shown in Table 2. 
Table 2. CT tests before and after doxycycline/azithromycin treatment. All data are presented as the mean $\pm \mathrm{SD}$, minimum, maximum and/or frequencies in percent (\%).

\begin{tabular}{|c|c|c|c|c|}
\hline PA & MMET & & $\begin{array}{l}\text { Doxycy- } \\
\text { cline }\end{array}$ & $\begin{array}{l}\text { Azitromy- } \\
\text { cine }\end{array}$ \\
\hline & Before & positive & $20(100 \%)$ & $20(100 \%)$ \\
\hline smear on & therapy & negative & $0(0 \%)$ & $0(0 \%)$ \\
\hline Chlamydia & After & positive & $3(15 \%)$ & 17 (85\%) \\
\hline & therapy & negative & 17 (85\%) & 3 (15\%) \\
\hline
\end{tabular}

Table 3. Results of univariate logistic regression analyses of different parameters among groups. Asterisk $\left(^{*}\right)$ represents statistical significance $(p<0.05)$.

\begin{tabular}{|c|c|c|c|}
\hline PARAMETERS & $\begin{array}{c}\text { Regression } \\
\text { coefficient } \\
(\mathbf{R})\end{array}$ & $\begin{array}{c}\text { Relative } \\
\text { riskexp } \\
(\mathbf{B})=\mathbf{R} \mathbf{R}\end{array}$ & $\begin{array}{c}\text { Significance } \\
(p)\end{array}$ \\
\hline Overage age & 0.11 & 0.902 & 0.102 \\
\hline Marital status & 0.000 & 0.027 & 0.810 \\
\hline Age of sexual relations & -0.25 & 0.7 & $0.019^{*}$ \\
\hline Number of partners & 0.000 & 1.042 & 0.839 \\
\hline $\begin{array}{c}\text { Number of spontaneus } \\
\text { abortions }\end{array}$ & 0.000 & 1.189 & 0.617 \\
\hline $\begin{array}{c}\text { Number of intended } \\
\text { abortion }\end{array}$ & 0.000 & 1.323 & 0.837 \\
\hline Number of births & 0.000 & 1 & 0.989 \\
\hline Contraception & 0.000 & 1.286 & 0.724 \\
\hline Type of contraception & 0.000 & 1.185 & 0.887 \\
\hline Presence of clinical & 0.000 & 0.643 & 0.568 \\
\hline symptoms & 0.000 & 1 & 0.545 \\
\hline Clinical symptoms & 0.000 & 1.489 & 0.412 \\
\hline Diagnosis & -0.490 & 0.031 & $0.0001^{*}$ \\
\hline Therapy & & & \\
\hline
\end{tabular}

Table 4. Results of multivariate logistic regression used for analysis of impact before treatment and treatment factors for results. Asterisk (*) represents statistical significance $(p<0.05)$.

\begin{tabular}{|c|c|c|c|}
\hline PARAMETERS & $\begin{array}{c}\text { Regression } \\
\text { coefficient } \\
(\mathbf{R})\end{array}$ & $\begin{array}{c}\text { Relative } \\
\text { risk exp } \\
(\mathbf{B})=\mathbf{R}\end{array}$ & $\begin{array}{c}\text { Signifi- } \\
\text { cance } \\
(p)\end{array}$ \\
\hline Age of sexual relations & 0.000 & 0.988 & 0.953 \\
\hline Therapy & -0.387 & 0.0323 & $0.0013^{*}$ \\
\hline
\end{tabular}

The Chlamydia findings in the cervix smear before and after implementation of azithromycin did not significantly differ (Mc Nemar test $\mathrm{p}=0.250$ ). All respondents who were treated with this antibiotic before the application had a positive Chlamydia cervix smear. After therapy, $85 \%$ of the patients had a positive smear finding, and $15 \%$ of the patients who were positive before therapy had a negative smear.

\section{Univariate logistic regression analyses among} groups

The results of univariate logistic regression were used to analyse the impact of treatment factors on the treatment outcome. Univariate analysis showed that the years of sexual relations and type of treatment were statistically significant. Patients who had previously entered into their first sexual relations had a higher percentage of treatment failure, and their risk of bad outcome was 1.5 times higher. Treatment with doxycycline, in infections caused by chlamydia, is shown to be significantly more successful than treatment with azithromycin. Based on the relative risk for bad outcomes, which in this case is represented by a positive Chlamydia swab result and after the conducted treatment, therapy efficiency was 32 times higher than the treatment efficiency with azithromycin (Table 3).

\section{Multivariate logistic regression analyses among groups}

In the multivariate model, the two above-mentioned factors were statistically significant: age of sexual relations and applied therapy. Relative risk in the multivariate model showed that doxycycline in relation to azithromycin is 30 times more efficient in the treatment of infections caused by chlamydia (Table 4 ).

\section{DISCUSSION}

This single-centre, randomized prospective study was conducted among 40 women who were diagnosed with Chlamydia Trachomatis (CT) cervical infections to test the efficacy of the proposed treatment protocol for trachomatis Chlamydia genital infections in reproductive age women.

Chlamydia trachomatis, a small gram-negative bacterium, is the most common cause of bacterial sexually transmitted infections (STI) in both men and women (6). In the United States, it is the most commonly reported nationally notifiable disease (5-9). A significant proportion of patients are asymptomatic, thereby providing an ongoing reservoir for infection. The most frequent clinical manifestation of chlamydial infection in men is urethritis, and the most common finding in women is cervicitis. Thus, managing these conditions is essential.

Several factors should affect the decision to provide presumptive therapy for cervicitis.

Oral treatment with $100 \mathrm{mg}$ of doxycycline taken twice daily for 7 days or with a single 1-g dose of azithromycin has been recommended since 1996 (6).

Previous research showed that there are significant differences in the efficiency of treating chlamydia trachomatis with doxycycline and azithromycin. Schwepeke and co-authors, in a large study in a male population diagnosed with Chl. trachomatis, showed that efficiency with doxy- 
cycline was $95 \%$ in relation to azithromycin (77\%) (26). Later, Kong and co-authors showed even less efficiency with doxycycline in relation to azithromycin than to the earlier study $(27,28)$. A metanalysis by Kong showed a minimal difference of 2-6\% with doxycycline in relation to azithromycin. In our study, only $15 \%$ of patients had a positive cervical smear for chlamydia after therapy in the group treated with doxycycline.

The literature suggests a lower efficacy of azithromycin, but the reasons for this remain unclear. In groups with very similar demographic and anamnestic characteristics, differences between treated groups were significant (Tables 2 and 3). Univariate analysis showed that the year of sexual relations and the type of treatment were found to be significant. Patients who had previously entered in the first sexual relations had a higher percentage of treatment failure, and their risk of a poor outcome was 1.5 times higher. Treatment with doxycycline in infections caused by chlamydia is shown to be significantly more successful than is treatment with azithromycin. Based on the value of the relative risk for bad outcomes, which in this case is represented by a positive chlamydia swab result after treatment, the efficiency of the therapy was 32 times higher than the treatment efficiency with azithromycin (Table 3). One of the possible explanations of this result may be in the adherence of therapy in both groups. In fact, doxiciclyn (Dovicin ${ }^{\circ}$ ) was used in a dose of $100 \mathrm{mg}$ twice per day for 10 days, whereas azithromycin (Hemomycin $^{\odot}$ ) was used in a dose of $1000 \mathrm{mg}$ per day, divided into four doses or a single dose per day. These differences in dosing type can be a limiting factor for therapy efficiency because of the lower adherence in the macrolides group.

Furthermore, the multivariate model showed that the two above-mentioned factors were statistically significant: age of sexual relations and applied therapy. The relative risk in the multivariate model showed that doxycycline in relation to azithromycin was 30 times more efficient in the treatment infections caused by chlamydia (Table 4).

Our results are completely in accordance with previous study results. Geisler et al concluded that in the context of a closed population receiving directly observed treatment for urogenital chlamydia infection, the efficacy of azithromycin was $97 \%$, and the efficacy of doxycycline was $100 \%$ (38). Additionally, other studies have shown a lower efficacy for azithromycin compared with doxycycline. A metaanalysis of 23 randomized trials indicated that the efficacy of doxycycline was 3 percentage points higher than that of azithromycin for the treatment of urogenital chlamydia and was 7 percentage points higher than that of azithromycin for the treatment of symptomatic males; this resulted in renewed recommendations for trials to address the noninferiority of azithromycin (39).

In that sense, Lusk and coworkers concluded that empiric azithromycin treatment of cervicitis reduces cervicitis at follow-up in populations with a high prevalence of chlamydia trachomatis and/or mycoplasma genitalium, but there were no benefits of empiric azithromycin for non-specific cervicitis or empiric partner treatment (40).
These results suggest that there is a difference in the efficacy of the mentioned medicines, but we cannot dismiss the possibility that azithromycin can be effective in treating urogenital infection caused by $\mathrm{CT}$ as well as chlamydial cervicitis in women.

The literature describes therapy for cervical infection caused by chlamydia trachomatis as tetracycline and macrolide antibiotics, and the efficiency of these drugs based on results of most authors is almost equal (28-30). When we compared the dose-effective potential of these medications, the dose was almost empirically established. A previous study noted that $1000 \mathrm{mg}$ of azithromycin was equally efficient in the treatment of chlamydia trachomatis as doxycycline applied in $200 \mathrm{mg}$ doses per day for 7 days $(31,32)$.

Our study treatment protocol was a little different. We applied azithromycin in a single dose of $1000 \mathrm{mg}$ and doxycycline at a dose of $100 \mathrm{mg}$ for 10 days twice per day and later in a single dose. Our results show that doxycycline was significantly more efficient in the treatment of cervical infection caused by chlamydia trachomatis compared to azithromycin treatment. These differences in administration type did not influence the efficacy of the treatments separately, but generally, the frequency of oral intake of medicine can be a reason for lower adherence and, thus, indirectly for efficiency (33-35). In settings in which adherence is questionable, a single oral 1-g dose of azithromycin remains an excellent option because of the ease of its use and administration, in contrast to doxycycline.

However, treatment with azithromycin is almost half the price of treatment with doxycycline. Therefore, because of economic reasons, in some countries, the first choice of treatment for cervical infections caused by chlamydia trachomatis is azithromycin $(36,37)$.

In our study, in the group treated with doxycycline, after the therapy, $15 \%$ of the patients had a positive smear finding, whereas in the group treated with azithromycin, chlamydia trachomatis after therapy was found in $85 \%$ of the patients.

However, the reasons for the lower efficacy of azithromycin remain unclear. Drug resistance of chlamydia has not been definitively established. Some patients may not have sustained mucosal levels of azithromycin that are sufficient to eradicate chlamydia, and the infection may therefore be driven to a persistent viable state. It is of interest, however, that azithromycin may be more efficacious for treating an upper reproductive tract infection. In a macaque model of pelvic inflammatory disease, azithromycin reduced inflammation and was more effective in eradicating chlamydia from the lower and upper reproductive tract (in 12 of 12 animals) compared with doxycycline (7 of 12 animals) (41). Thus, with the above caveats in mind, it does not seem reasonable to recommend doxycycline over azithromycin as the preferred regimen for chlamydia treatment.

The limitations of this study include a small observed sample of women, particularly with regard to the directly observed administration of the single dose of azithromy- 
cin. Because of the finding of very high efficacy for both treatments, we believe that the current therapy empirical recommendation that either drug be used in the treatment of persons with a chlamydia infection seems appropriate and remains valid.

\section{CONCLUSION}

Our results confirm that the outcome of infections caused by $\mathrm{C}$. trachomatis depends solely on applied therapy and management, but extensive prospective studies in a female cohort with more included parameters, such as potential age-related, dose-dependent and adherence variability, are necessary to determine and confirm the best choice for treatment of CT cervicitis.

\section{Acknowledgements}

This study was conducted with the approval of the Clinical Center Kragujevac Ethics Committee. We thank the staff and patients of The Clinic of Obstetrics and Gynaecology, Clinical Center Kragujevac in Serbia.

\section{Potential conflicts of interest}

All authors: No reported conflicts.

\section{REFERENCES}

1. Thompson, Sumner E., and A Eugene Washington. Epidemiology of sexually transmitted Chlamydia trachomatis infections. Epidemiologic reviews 5 (1983): 96.

2. Walker, Jennifer, et al. Chlamydia trachomatis incidence and re-infection among young women-behavioural and microbiological characteristics. PloS one 7.5 (2012): e37778.

3. Weinstock, Hillard, Stuart Berman, and Willard Cates. Sexually transmitted diseases among American youth: incidence and prevalence estimates, 2000. Perspectives on sexual and reproductive health 36.1 (2004): 6-10.

4. Stamm, Walter E. Chlamydia trachomatis infections: progress and problems. Journal of Infectious Diseases 179.Supplement 2 (1999): S380-S383.

5. Fenton, Kevin A., et al. Sexual behaviour in Britain: reported sexually transmitted infections and prevalent genital Chlamydia trachomatis infection. The Lancet 358.9296 (2001): 1851-1854.

6. Morré, Servaas A., et al. The natural course of asymptomatic Chlamydia trachomatis infections: $45 \%$ clearance and no development of clinical PID after oneyear follow-up. International journal of STD \& AIDS 13.suppl 1 (2002): 12-18.

7. Cates, Willard, and Judith N. Wasserheit. Genital chlamydial infections: epidemiology and reproductive sequelae. American journal of obstetrics and gynecology 164.6 (1991): 1771-1781.
8. Satterwhite, Catherine Lindsey, et al. Sexually transmitted infections among US women and men: prevalence and incidence estimates, 2008. Sexually transmitted diseases 40.3 (2013): 187-193.

9. de Figueirêdo, Camila Macêdo, et al. Analysis Of Scientific Production On Ophthalmia Case Study Of Newborn And Its Relationship With The Type Of Birth And Preventive Methods: Systematic Review And MetaAnalysis. International Archives of Medicine 9.1 (2016).

10. Ferreira, Glenda Roberta Oliveira Naiff. Soroepidemiologia de Chlamydia trachomatis, Chlamydia pneumoniae e Treponema pallidum nas aldeias indígenas Bakajá, Apyterewa, Xingu e Mrotidjãm, Altamira, Pará, Brasil. (2010).

11. Haggerty, Catherine L., et al. Risk of sequelae after Chlamydia trachomatis genital infection in women. Journal of Infectious diseases 201.Supplement 2 (2010): S134-S155.

12. Jaschek, G., et al. Direct detection of Chlamydia trachomatis in urine specimens from symptomatic and asymptomatic men by using a rapid polymerase chain reaction assay. Journal of clinical microbiology 31.5 (1993): 1209-1212.

13. Morré, S. A., et al. Urogenital Chlamydia trachomatis serovars in men and women with a symptomatic or asymptomatic infection: an association with clinical manifestations?. Journal of Clinical Microbiology 38.6 (2000): 2292-2296.

14. Lee, Helen H., et al. Diagnosis of Chlamydia trachomatis genitourinary infection in women by ligase chain reaction assay of urine. The Lancet 345.8944 (1995): 213-216.

15. Stephens, R. S., et al. Monoclonal antibodies to Chlamydia trachomatis: antibody specificities and antigen characterization. The Journal of Immunology 128.3 (1982): 1083-1089.

16. Ratti, Giulio. Chlamydia trachomatis antigens. U.S. Patent No. 8,114,401. 14 Feb. 2012.

17. Chen, Ding, et al. Characterization of Pgp3, a Chlamydia trachomatis plasmid-encoded immunodominant antigen. Journal of bacteriology 192.22 (2010): 6017-6024.

18. Baud, D., L. Regan, and G. Greub. Comparison of five commercial serological tests for the detection of antiChlamydia trachomatis antibodies. European journal of clinical microbiology \& infectious diseases 29.6 (2010): 669-675.

19. Stevens, Matthew P., et al. Development and evaluation of an ompA quantitative real-time PCR assay for Chlamydia trachomatis serovar determination. Journal of clinical microbiology 48.6 (2010): 2060-2065.

20. Horner, Paddy J. Azithromycin antimicrobial resistance and genital Chlamydia trachomatis infection: duration of therapy may be the key to improving efficacy. Sexually transmitted infections 88.3 (2012): 154-156.

21. Lanjouw, E., et al. 2010 European guideline for the management of Chlamydia trachomatis infections. International journal of STD \& AIDS 21.11 (2010): 729-737. 
22. Bhengraj, Apurb Rashmi, et al. Decreased susceptibility to azithromycin and doxycycline in clinical isolates of Chlamydia trachomatis obtained from recurrently infected female patients in India. Chemotherapy 56.5 (2010): 371-377.

23. Pitsouni, Eleni, et al. Single-dose azithromycin versus erythromycin or amoxicillin for Chlamydia trachomatis infection during pregnancy: a meta-analysis of randomised controlled trials. International journal of antimicrobial agents 30.3 (2007): 213-221.

24. Hathorn, Emma, Catherine Opie, and Penny Goold. What is the appropriate treatment for the management of rectal Chlamydia trachomatis in men and women? Sexually transmitted infections 88.5 (2012): 352-354.

25. Thorpe, E. M., et al. Chlamydial cervicitis and urethritis: single dose treatment compared with doxycycline for seven days in community based practises. Genitourinary medicine 72.2 (1996): 93-97.

26. Schwebke, J. R., et al. Re-evaluating the treatment of nongonococcal urethritis: emphasizing emerging pathogens-a randomized clinical trial. Clinical Infectious Diseases 52.2 (2011): 163-170.

27. Kong, F. Y. S., et al. Azithromycin versus doxycycline for the treatment of genital chlamydia infection-a meta-analysis of randomised controlled trials. Clinical Infectious Diseases (2014): ciu220.

28. Kong, Fabian Yuh Shiong, and Jane Simone Hocking. Treatment challenges for urogenital and anorectal Chlamydia trachomatis. BMC infectious diseases 15.1 (2015): 1.

29. Kissinger, Patricia J., et al. Azithromycin treatment failure for Chlamydia trachomatis among heterosexual men with nongonococcal urethritis. Sexually Transmitted Diseases 43.10 (2016): 599-602.

30. Lau, Chuen-Yen, and Azhar K. Qureshi. Azithromycin versus doxycycline for genital chlamydial infections: a meta-analysis of randomized clinical trials. Sexually transmitted diseases 29.9 (2002): 497-502.

31. Rustomjee, Roxana, et al. A randomized controlled trial of azithromycin versus doxycycline/ciprofloxacin for the syndromic management of sexually transmitted infections in a resource-poor setting. Journal of Antimicrobial Chemotherapy 49.5 (2002): 875-878.

32. Gambini, Daniele, et al. Mycoplasma genitaliumin Males With Nongonococcal Urethritis: Prevalence and Clinical Efficacy of Eradication. Sexually transmitted diseases 27.4 (2000): 226-229.

33. Ibrahim Salah Eldin. Evaluation Of Azithromycin In Treatment Of Avulgaris. Diss. UOFK, 2015.

34. Manhart, Lisa E., et al. Efficacy of antimicrobial therapy for Mycoplasma genitalium infections. Clinical Infectious Diseases 61.suppl 8 (2015): S802-S817.

35. Perletti, Gianpaolo, et al. Antimicrobial therapy for chronic bacterial prostatitis. The Cochrane Library (2013).

36. Haddix, Anne C., Susan D. Hillis, and William J. Kassler. The cost effectiveness of azithromycin for Chlamydia trachomatis infections in women. Sexually Transmitted Diseases 22.5 (1995): 274-280.

37. Genc, Mehmet, and Per-Anders Mardh. A cost-effectiveness analysis of screening and treatment for Chlamydia trachomatis infection in asymptomatic women. Annals of Internal Medicine 124.1_Part_1 (1996): 1-7. 